\section{Psykiatri i et samfunnsperspektiv}

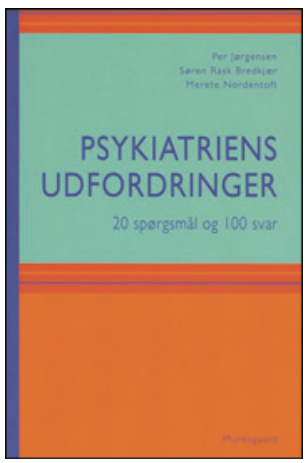

Per Jørgensen, Søren Rask Bredkjær, Merete Nordentoft

Psykiatriens udfordringer

20 spørgsmål og 100 svar. 152 s, ill.

København: Munksgaard Danmark, 2012

Pris DKK 178

ISBN 978-87-6281-143-0

Intensjonen er å gi enkle og løsningsorienterte svar på dagsaktuelle spørsmål om behandling og organisering av helsetjenesten for personer med psykiske lidelser. De 20 kapitlene er inndelt i tre deler, som omhandler følgende temaer: avstigmatisering og pasientinvolvering, faglige forhold og organisatoriske forhold. Forfatterne er alle danske spesialister i psykiatri, de to førstnevnte med lang erfaring som ledere av omfattende kliniske enheter, og sistnevnte som professor og internasjonalt kjent forsker, særlig innen områdene selvmordsforebygging og tidlig intervensjon ved psykoser. Med hensyn til lovgivning og retningslinjer er boken tilpasset danske forhold, men relevant også for norske forhold.

Eksempler på temaer som tas opp, er grenseoppgangen mellom primær- og spesialisthelsetjenesten, samhandlingsforhold og utviklingen og problemene knyttet til spesialisering av tilbudene. Spesialiseringen kan være nyttig for fagutvikling og forskning. Den muliggjør utviklingen av en vifte av behandlingstilbud, som tilpasset psykoterapi, gruppebehandling og psykoedukasjon med systematisk medvirkning av pårørende. Men forfatterne påpeker mangelen på gode tilbud for de mange pasientene som har flere forskjellige sykdommer, eksemplifisert som middelaldrende pasienter med dårlig sosial funksjonsevne, manglende sosialt nettverk, interpersonelle konflikter, kroniske somatiske sykdommer, liten formell utdanning, dårlig økonomi, tendens til uhensiktsmessige handlingsmønstre i pressede situasjoner som de stadig befinner seg i, og dessuten rusmisbruk. Her er det behov for bred innsats som innbefatter både somatikk, psykiatri og sosialfag, og ikke bare spesialisert psykiatrisk symptombehandling.

Man regner med at bare omtrent halvparten av pasientene med alvorlige psykiske lidelser i de vestlige land får behandling, og ofte er behandlingen som gis, ikke i overensstemmelse med kunnskapsbaserte retningslinjer. Underbehandlingen rammer særlig unge uten utdanning eller arbeid. Psykiatrien har således bruk for flere velutdannede og dedikerte medarbeidere. Personalet er den viktigste ressursen, og forfatterne anbefaler at man gjør store anstrengelser for å sikre personalet gode arbeidsforhold og utviklingsmuligheter.

Målgruppen er først og fremst leger, psykologer og sykepleiere innen psykiatrien. Boken er imidlertid vel så viktig for ledere, politikere og administratorer innen psykisk helsevern. Den skjemmes av at forfatterne ureflektert beskriver sykdomsforløpet hos gjerningsmannen i regjeringskvartalet og på Utøya 22. juli 2011 som typisk for alvorlig schizofreniutvikling. De har åpenbart lagt den første rettspsykiatriske rapporten til grunn og ikke fått med seg den videre utviklingen i saken før manus ble innlevert. Dette ødelegger imidlertid ikke hovedinntrykket.

Universitetet i Oslo

\section{Veldig kort om transplantasjon}

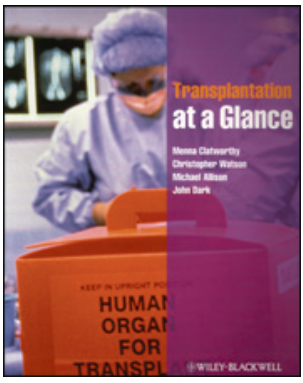

Menna Clatworthy, Christopher Watson,

Michael Allison et al.

Transplantation at a glance

104 s, tab, ill. Chichester: Wiley-Blackwell,

2012. Pris GBP 25

ISBN 978-0-470-65842-0

Boken kommer ut i serien At a glance. Intensjonen er å bryte komplekse problemstillinger ned til korte illustrerte tekster. Denne gangen er temaet organtransplantasjon. Målgruppen er primært studenter, men også leger som møter transplanterte pasienter i sitt arbeid.

Språket er presist og kortfattet. Kapitlene er godt definert med underpunkter. Det er generelt lett å orientere seg i teksten. Hvert tema er stort sett begrenset til én side med tilhørende illustrasjon på motsatt side. Sidestørrelsen er tilstrekkelig stor til at lesbarheten i figurer er bevart. Boken har ikke fast omslag og er ikke helt ulikt tidsskriftet i størrelse. Den egner seg således ikke til å putte i frakkelommen.

Forfatterne gir først en basal innføring i organpreservering og donasjon samt immunologi og medikamentelle strategier, inkludert komplikasjoner av immundempende behandling. Deretter følger organspesifikke kapitler for nyre, pancreas, lever, hjerte og lunge.

Kapitlene om nyretransplantasjon dominerer og inkluderer nyresvikt, dialyse, kirurgiske teknikker med komplikasjoner og forsinket graftfunksjon, akutte rejeksjoner og kronisk allograft nefropati.

I tillegg omtales kort intestinal transplantasjon, vevstransplantasjon og betraktninger rundt xenotransplantasjon.

Forfatterne har klart å skape et rammeverktøy for klinikere som ikke arbeider med transplantasjon til daglig. Teksten er et greit utgangspunkt for videre fordypning. Sett fra indremedisinsk side utgjør spesielt den kirurgiske vinklingen et nyttig supplement.

Ønsker man en kort, illustrert innfallsvinkel til organtransplantasjon uten de helt store litterære utfordringene, kan denne boken være verdt et forsøk.

Morten Reier-Nilsen

Nyreseksjonen

Drammen sykehus 